\title{
Effect of Hevea brasiliensis latex sap gel on healing of acute skin wounds induced on the back of rats
}

\section{Efeito do gel da seiva do látex da Hevea brasiliensis na cicatrização de lesões cutâneas agudas induzidas no dorso de ratos}

\author{
Maria Vitória Carmo Penhavel ${ }^{1}$; Victor Henrique Tavares ${ }^{1}$; Fabiana Pirani Carneiro ${ }^{1}$; João Batista de Sousa ${ }^{1}$
}

\author{
A B S S T R A C T
}

\begin{abstract}
Objective: to evaluate the effect of topical delivery of latex cream-gel in acute cutaneous wounds induced on the back of rats. Methods: we subjected sixteen rats to dermo-epidermal excision of a round dorsal skin flap, with $2.5 \mathrm{~cm}$ diameter. We divided the animals into two groups: Latex Group: application of cream-gel-based latex throughout the wound bed on postoperative days zero, three, six and nine; Control group: no treatment on the wound. Photographs of the lesions were taken on the procedure day and on the $6^{\text {th }}$ and $14^{\text {th }}$ postoperative days, for analyzing the area and the larger diameter of the wound. We carried out euthanasia of all animals on the $14^{\text {th }}$ postoperative day, when we resected he dorsal skin and the underlying muscle layer supporting the wound for histopathological study. Results: there was no statistically significant difference in the percentage of wound closure, in the histopathological findings or in the reduction of the area and of the largest diameter of the wounds among the groups studied on the $14^{\text {th }}$ postoperative day. Conclusion: according to the experimental conditions in which the study was conducted, latex cream-gel did not interfere in the healing of acute cutaneous wounds in rats.
\end{abstract}

Key words: Wound healing. Latex. Treatment. Skin. Rats.

\section{INTRODUCTION}

W ound healing consists of a coordinated cascade of cellular and molecular events that interact to enable tissue reconstruction. Tissue loss is a triggering factor for wound healing and it initiates a series of steps that overlap from time to time. It includes inflammation, neoformation and tissue remodeling. Immediately after injury, the healing process begins through the action of a series of growth factors, cytokines and substances released from platelets and damaged blood vessels. After blood clots are formed, inflammatory cells invade the tissue and exert protecting functions against contaminating microorganisms. They are also major sources of growth factors and cytokines that trigger the wound healing proliferative phase. Such phase, in turn, begins with the migration and proliferation of keratinocytes at the wound edges, followed by the multiplication of dermal fibroblasts in the vicinities of the damaged tissue. Subsequently, the fibroblasts begin to produce large quantities of extracellular matrix. Still in the proliferative phase, there is formation of granulation tissue, thus named because of the granular characteristic due to the presence of newly formed capillaries that are essential to the healing process. Finally, there is the transition of the granulation tissue into a mature scar, which is characterized by collagen continuous synthesis and degradation. The scar is a mechanically insufficient tissue, which lack epidermal appendages ${ }^{1,2}$.

Since ancient times, mankind tries to interfere in the tissue repair process. In recent decades, much effort has been made in identifying substances and techniques capable to promote healing to be used in wound management. The search for substances with angiogenic activity has also been intense due to its strong potential for clinical application. However, wound healing still remains a challenging clinical issue ${ }^{3}$.

The use of natural latex from Hevea Braziliensis rubber tree for medicinal purposes is an alternative that links biocompatibility and low cost. Several studies have suggested that latex presents growth factors capable of acting in human tissues by stimulating neovascularization, cell adhesion and the formation of extracellular matrix, although such action mechanisms has not been fully elucidated so far ${ }^{4}$. Rubber tree latex biomembrane was developed by Coutinho-Netto for therapeutic purposes in the Laboratory of Biochemistry at the Medical School, USP, Ribeirão Preto / SP. In 1996, the first study used this material for the reconstruction of experimental defects in the

1. Faculdade de Medicina da Universidade de Brasília (UnB), Brasília, DF, Brasil. 
esophagus of dogs. It demonstated its influence on tissue neoformation, suggesting the possibility of its use as a substitute or a trigger to the formation of organs and tissues, although there has been elimination of the material ${ }^{5}$. Subsequent experimental studies have demonstrated the action of the biomembrane favoring the repair of abdominal wall defects in rats ${ }^{6}$, conjunctival reconstruction in rabbits $^{7}$, as a prosthesis in videolaparoscopic inguinoplasty in $\operatorname{dogs}^{8}$, in the lining of the open cavity in tympanomastoidectomies ${ }^{9}$ and pericardium replacement in dogs $^{10}$. The biocompatibility of the biomembrane, necessary for its use as a biomaterial, has been proven by a number of experimental studies ${ }^{11,12,13}$. The biomembrane, in the form of dressing, is useful for treating pressure ulcers, promoting rapid debridement, granulogenesis and healing acceleration ${ }^{14}$. Similar effects were observed in chronic flebopathic ulcers ${ }^{15}$.

Subsequent studies showed that the angiogenic and healing acceleration properties are due to the action of a protein substance found in the latex serum fraction ${ }^{4,16}$. Such discovery stimulated the development of a cream-gel for topical use, which is indicated for the treatment and healing of wounds, produced from the base serum containing the bioactive protein fractions added to a creamgel base.

This study aimed to evaluate the healing effect of latex cream-gel on induced skin wounds in rats.

\section{METHODS}

This study was performed at the Laboratory of Experimental Surgery at the Medical School, University of Brasilia, Brazil. We adopted the Ethical Principles in Animal Experimentation recommended by the Brazilian College of Animal Experimentation (COBEA - Colégio Brasileiro de Experimentação Animal) affiliated to the International Council for Laboratory Animal Science, and the Brazilian Legislation on Animal Experimentation, Federal Law No. 6638 (1979). The research project was submitted to and approved by the Ethics in Research Committee on Animal Use of the Medical School, University of Brasília (protocol approval number 52439/2011).

We studied 16 adult, male Wistar rats (Rattus norvegicus albinus, Rodentia mammalia), with mean age of 60 days and weighing between 188 and 386 grams. We established an acclimatization period of seven days before initiating the experiment. The animals remained in their own accommodation, under room temperature and humidity, in circadian cycle (light / dark), with free access to water and specific diet (Purina ${ }^{\circledR}$ - Labina).

\section{Experimental design}

We randomly distributed the animals into two groups, with eight animals each: Latex group - application of latex serum in cream-gel base on the wound bed on postoperative days zero, three, six and nine; Control group: no treatment on the wound. We performed euthanasia of all animals on the $14^{\text {th }}$ postoperative day.

\section{Surgical procedure}

We anesthetized the animals with xylazine hydrochloride at a dose of $10 \mathrm{mg} / \mathrm{kg}$ of body weight, combined with ketamine hydrochloride at a dose of $75 \mathrm{mg} /$ $\mathrm{kg}$ of body weight, intramuscularly delivered. Once anesthetized, each animal was placed on the surgical board in prone position. After trichotomy, the surgical technique started, with the same standardization for the animals in all groups, as we previously described in another publication ${ }^{17}$. The center of the epilated region was previously marked with a metallic, $2.5 \mathrm{~cm}$ diameter dermatological punch, and the excision of the skin was completed with a scalpel (figure 1). Hemostasis was performed by digital compression with gauze. Then, the animals from the latex group received manual application of latex in cream-gel base, in an amount enough to cover the surface of the wound. In the control group, the lesion was induced, followed only by hemostasis.

The latex cream-gel was reapplied on the third, sixth and ninth postoperative days. All animals, including the ones from the control group, were anesthetized on the mentioned days above. On the third and ninth days, the experimental animals were anesthetized for proper application of the gel-cream on the wound, and the control ones so that the animals were exposed to the same stressful situations, except the application of gel-cream.

Neither group received occlusive dressing after the treatments were applied. At the end of the procedures, the animals were put back in their respective cages, in the same preoperative conditions.

\section{Documentation of the wounds evolution}

Once the animals were fixed on the operating table, the largest and smallest diameters of the wounds were measured with the help of a caliper in order to be

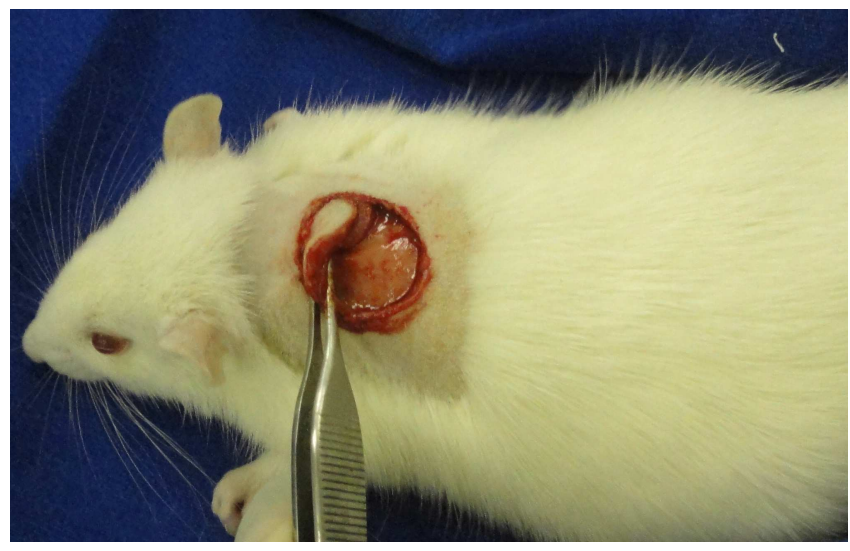

Figure 1 - Excision of the skin. Detail of the area marked by the punch and sectioned, deeply limited by the muscular plane. 
compared with the standard initial measurement. At that time, we recorded the wounds with digital photography. This procedure was performed on the day the surgery was appointed to happen, and repeated on the $6^{\text {th }}$ and on the $14^{\text {th }}$ postoperative days. The image of the lesion was transferred to the Image $\mathrm{B}$ software, and after establishing the periphery by means of the polyline method (demarcation of all points of the injury), the wound image was analyzed according to area and the largest diameter parameters.

\section{Material collection for the study}

On the $14^{\text {th }}$ postoperative day, the 16 animals were anesthetized with intramuscular ketamine and xylazine. Then, a dorsal pad containing the wound and the underlying muscle layer was excised. The animals were sacrificed with a lethal dose of thiopental intraperitoneally delivered at a dose of $25 \mathrm{mg} / \mathrm{kg}$. The specimens were preserved in formaldehyde for histopathological study.

\section{Histopathology}

Fragments embedded in paraffin were stained with hematoxylin and eosin and examined under an optical microscope. We analyzed the amount of collagen, fibroblasts and mononuclear and polymorphonuclear infiltrates. These parameters were graded on a 0-3 scale, indicating, respectively, samples with no, little, moderate or great amounts of the analyzed variable. Neovessels were quantified in five high magnification fields. The presence or absence of reepithelialization, foreign body, abscess and hair follicles in the scar were also documented.

\section{Statistical analysis}

Data were analyzed using the Sigma Stat@ 3.5 software. Comparisons of areas and the larger diameters of the wounds in latex and control groups in each of the study days were done by One Way Analysis of Variance (ANOVA). The Fisher's Exact and Chi-square tests were used for histological variables. The significance level ( $p$ ) used for rejecting the null hypothesis was 0.05.

\section{RESULTS}

\section{Measurements of the wounds}

when comparing the control and the latex groups on the day the surgery was performed, on the $6^{\text {th }}$ and on the $14^{\text {th }}$ postoperative days, the wound area did not show a statistically significant difference (Table 1).

The percentage of wound closure from day zero to day six showed no statistically significant difference in the intergroup comparison ( $p=0.136)$. There was, however, a higher wound closure percentage in the latex group compared with the control one, $63.1 \%$ and $59.5 \%$, respectively.

\section{Microscopic evaluation}

Tables 2, 3 and 4 show the histological intergroup comparison on the $14^{\text {th }}$ postoperative day, with no statistically significant difference, though the number of neovessels in the latex group, observed in higher magnifications microscopic fields, was higher when compared with the control group (Figure 2).

\section{DISCUSSION}

Several researches have shown that the biomembrane produced from natural latex of Hevea brasiliensis is biocompatible and has angiogenic, cell adhesion and extracellular matrix formation properties ${ }^{11}$. In pressure ulcers, the biomembrane facilitated the rapid debridement of wounds, granulogenesis and complete healing, producing flat and aesthetic scars ${ }^{14}$. Similar results were observed in diabetic patients with abnormal wound healing ${ }^{18}$. When used in patients with chronic venous ulcers, the biomembrane worked as a wound healing inducing factor, particularly in the inflammatory phase, confirmed by the intense exudation and debridement of the lesions, leading to changes in the chronic venous ulcer microenvironment ${ }^{19}$.

The preparation of a latex gel containing the protein fractions responsible for the induction of angiogenesis corresponds to the biotechnological enhancement of the research on Hevea brasiliensis natural latex. The product was obtained by a technique used to separate protein fractions through a high performance liquid chromatography, lyophilization and cream-gel formulation. According to studies conducted by the manufacturer, the protein fractions show biological activities that stimulate angiogenesis, fibroblasts cell proliferation, collagen synthesis and extracellular matrix strengthening and collagenase inhibition ${ }^{20}$. A study using latex gel in patients with chronic ulcers was also conducted by the same group with favorable results.

Table 1 - Areas of the lesions (in $\mathrm{cm}^{2}$ ) in the latex and control groups.

\begin{tabular}{lrlcc}
\hline Day of experiment & Control $(n=8)$ & Mean \pm SD & Latex $(n=7)$ Mean \pm SD & $p$ \\
\hline 0 & $4.17 \pm 0.88$ & $4.44 \pm 0.88$ & 0.544 \\
6 & $1.69 \pm 0.52$ & $1.60 \pm 0.44$ & 0.711 \\
14 & $0.04 \pm 0.04$ & $0.06 \pm 0.03$ & 0.083 \\
\hline
\end{tabular}


Table 2 - $\quad$ Histological comparison between the control and the latex groups on the $14^{\text {th }}$ postoperative day.

\begin{tabular}{lcccc}
\hline & \multicolumn{2}{c}{ Control $(\mathrm{n}=8)$} & \multicolumn{2}{c}{ Latex $(\mathrm{n}=8)$} \\
& Mean & Max/min & Mean & Max/min \\
\hline Collagen & 2.0 & $2 / 2$ & 2.0 & $2 / 2$ \\
Fibroblasts & 3.0 & $3 / 3$ & 3.0 & $3 / 3$ \\
Mononuclear & 2.0 & $2 / 2$ & 2.0 & $2 / 2$ \\
Polymorphonuclear & 2.0 & $2 / 2$ & 2.0 & $2 / 2$ \\
Epithelial hyperplasia & 1.4 & $2 / 1$ & $1.8^{*}$ & $2 / 1$ \\
\hline
\end{tabular}

* Latex $x$ control $p=0.234$

Table 3 - Histological comparison between the control and the latex group in the 14th postoperative day (2).

\begin{tabular}{lcccc}
\hline & \multicolumn{2}{c}{ Control $(n=8)$} & \multicolumn{2}{c}{ Latex $(n=8)$} \\
& Present & Absent & Present & Absent \\
\hline Hair follicle & 0 & 8 & 0 & 8 \\
Abscess & 0 & 8 & 0 & 8 \\
Foreign body & 8 & 0 & 8 & 0 \\
Epithelialization & 4 & 4 & 3 & 5 \\
\hline
\end{tabular}

Table 4 - Comparison between the control and the latex group - quantification of neovessels on the $14^{\text {th }}$ postoperative day.

\begin{tabular}{lccc}
\hline & Control $(n=8)$ Mean \pm SD & Latex $(n=8)$ Mean \pm SD & $p$ \\
\hline Vessels /field & $24.50 \pm 9.24$ & $26.25 \pm 12.41$ & 0.561 \\
\hline
\end{tabular}

In a study assessing the biocompatibility of the biomembrane, Mrué and colleagues assessed the biomaterial-induced healing by using a model of $0.5 \mathrm{~cm}$ circular acute skin ulcers induced in rabbits' ears. The group treated with biomembrane showed early epithelialization when compared with the control one, and in the histopathological samples, the presence of organized
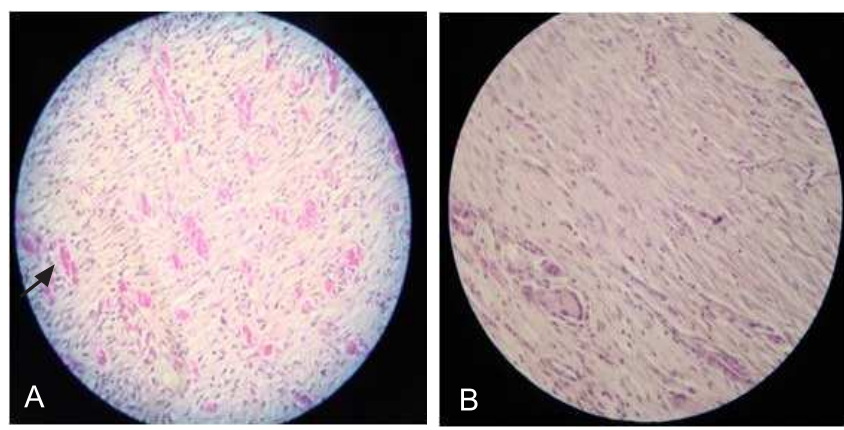

Figure 2 - $\quad$ Photomicrograph of the repair tissue from the rats' skin - 14 days after surgery. A=Latex group rat; $B=$ Control group. H\&E stain, 40x.

Note: neovessels in greater quantities in A (arrow) than in $B$. collagen fibers was evident and presented no sign of fibrosis and neovessels ${ }^{11}$.

We could not prove the effectiveness of latex gel as for wound area reduction and histopathological findings, since these parameters were not statistically significant when compared with the control group. In the study by Mrué ${ }^{11}$, the biomembrane flexible conformation allowed direct and permanent contact of the ulcer by means of stitches. In a study evaluating angiogenesis, vascular permeability and healing, the latex serum added to a carboxymethylcellulose gel was applied on the day of surgery and on the $3^{\text {rd }}, 6^{\text {th }}$ and $9^{\text {th }}$ postoperative days, showing accelerated healing ${ }^{16}$. The current study used latex with the same application frequency. However, unlike the above mentioned study, the ulcers have not received occlusive dressing after each application, which may have caused the product to stay less time in contact with the wound. These facts may have interfered in the observation of any difference between this and the other groups. Another limitation of this study is the sample size, with only eight animals in each group. A larger sample could increase its statistical power.

For further studies, we suggest that different quantities of the product should be used, in order to 
propose a dose, related to the size of the lesion, which is enough to promote a possible satisfactory effect. Serial biopsies of the lesions may also be useful to assess the influence of the latex cream-gel in specific healing evolutionary periods.

\section{CONCLUSION}

According to the experimental conditions in which the study was conducted, the latex cream-gel did not influence the healing of acute cutaneous wounds in rats.

\title{
R E S U M O
}

\begin{abstract}
Objetivo: avaliar o efeito da administração tópica do gel-creme de látex em feridas cutâneas agudas induzidas no dorso de ratos. Métodos: dezesseis ratos foram submetidos à excisão dermoepidérmica de retalho cutâneo dorsal, circular com $2,5 \mathrm{~cm}$ de diâmetro. Os animais foram distribuídos em dois grupos, um experimental e outro controle: Grupo Látex- aplicação em todo o leito da ferida do látex em base gel-creme no período zero, no terceiro, no sexto e no nono dias pós-operatórios; Grupo Controle- sem nenhum tratamento sobre a ferida. Foram feitas fotografias das lesões no dia da operação, no sexto e no $14^{\circ}$ dia pós-operatório, para análise de área e do maior diâmetro da ferida. Realizou-se a eutanásia de todos os animais no $14^{\circ}$ dia pós-operatório. Ressecou-se a pele dorsal e o plano muscular subjacente contendo a ferida para estudo histopatológico. Resultados: não houve diferença estatisticamente significante no percentual de fechamento, nos achados histopatológicos ou na redução da área e do maior diâmetro das feridas, entre os grupos estudados no $14^{\circ}$ dia pós-operatório. Conclusão: nas condições experimentais em que o estudo foi realizado, o gel-creme de látex não interferiu na cicatrização de feridas cutâneas agudas em ratos.
\end{abstract}

Descritores: Cicatrização. Látex. Terapêutica. Pele. Ratos.

\section{REFERENCES}

1. Mendonça RJ, Coutinho-Netto J. Aspectos celulares da cicatrização. An Bras Dermatol. 2009;84(3):257-62.

2. Werner S, Grose R. Regulation of wound healing by growth factors and cytokines. Physiol Rev. 2003;83(3):835-70.

3. Velnar T, Bailey T, Smrkolj V. The wound healing process: an overview of the cellular and molecular mechanisms. J Int Med Res. 2009;37(5):1528-42.

4. Mendonça RJ. Purificação e caracterização de uma proteína angiogênica, indutora de fibroplasia e cicatrizante presente no látex natural da seringueira Hevea brasiliensis [tese]. Ribeirão Preto: Universidade de São Paulo, Faculdade de Medicina de Ribeirão Preto; 2008

5. Mrué F. Substituição do esôfago cervical por prótese biossintética de látex. Estudo experimental em cães [dissertação]. Ribeirão Preto: Universidade de São Paulo, Faculdade de Medicina de Ribeirão Preto; 1996.

6. Ferreira PG. Avaliação do efeito da membrana de látex Hevea brasiliensis no reparo de defeito da parede abdominal de rato [dissertação]. Alfenas: Universidade Federal de Alfenas, Programa de Pós-Graduação em Ciências Farmacêuticas; 2009.

7. Pinho ECCM, Sousa SJF, Schaud F, Lachat JJ, Coutinho-Netto J. Uso experimental da biomembrana de látex na reconstrução conjuntival. Arq Bras Oftalmol. 2004;67(1):27-32.

8. Sousa LH, Ceneviva R, Coutinho-Netto J, Mrué F, Sousa Filho LH, Silva OC. Morphologic evaluation of the use of a latex prosthesis in videolaparoscopic inguinoplasty: an experimental study in dogs. Acta Cir Bras. 2011;26(Suppl 2):84-91.

9. Sousa LCA, Piza MRT, Coutinho-Netto J, Ruiz DB, Schmidt VB. Biomembrana de látex: novo método para o revestimento da cavidade aberta nas timpanomastoidectomias. Rev Bras Otorrinolaringol. 2007;73(3):331-6.

10. Sader SL, Coutinho Netto J, Barbieri Neto J, Mazzetto SA, Alves Júnior $\mathrm{P}$, Vanni JC, et al. Substituição parcial do pericárdio de cães por membrana de látex natural. Rev Bras Cir Cardiovasc. 2000;15(4):338-44.
11. Mrue F, Netto JC, Ceneviva R, Lachat JJ, Thomazini JA, Tambelini $\mathrm{H}$. Evaluation of the biocompatibility of a new biomembrane. Mat Res. 2004;7(2):277-83.

12. Zimmermann M, Raiser AG, Barbosa ALT, Novosad D, Steffen RPB, Lukarsewsk $R$, et al. Teste de biocompatibilidade e resistência de membranas de látex em cães. Ciênc Rural. 2007;37(6):171923.

13. Frade MAC, Coutinho Netto J, Gomes FG, Mazzucato EL, Andrade TAM, Foss NT. Curativo de biomembrana vegetal e hipersensibilidade. An Bras Dermatol. 2011;86(5):885-91.

14. Frade MAC, Salathiel AM, Mazzucato EL, Coutinho Netto J, Foss NT. A natural biomembrane as a new proposal for the treatment of pressure ulcers. Med Cutan Iber Lat Am. 2006;34(3):137-42.

15. Frade MA, Valverde RV, de Assis RV, Coutinho-Netto J, Foss NT. Chronic phlebopathic cutaneous ulcer: a therapeutic proposal. Int J Dermatol. 2001;40(3):238-40.

16. Mendonça RJ, Maurício VB, Teixeira LdeB, Lachat JJ, CoutinhoNetto J. Increased vascular permeability, angiogenesis and wound healing induced by the serum of natural latex of the rubber tree Hevea brasiliensisl. Phytother Res. 2010;24(5):764-8.

17. Penhavel MVC, Nascimento VHT, Durães EFR, Carneiro FP, Sousa JB. Effects of carbon dioxide therapy on the healing of acute skin wounds induced on the back of rats. Acta Cir Bras. 2013;28(5):3349.

18. Frade MA, Cursi IB, Andrade FF, Coutinho-Netto J, Barbetacc FM, Foss NT. Management of diabetic skin wounds with a natural latex biomembrane. Med Cutan Iber Lat Am. 2004;32(4):157-62.

19. Frade MAC, Assis RVC, Coutinho Netto J, Andrade TAM, Foss NT. The vegetal biomembrane in the healing of chronic venous ulcers. An Bras Dermatol. 2012;87(1):45-51.

20. Pelenova Biotecnologia, Valeant Farmacêutica do Brasil. Avanço Tecnológico para recomposição cutânea. Monografia de produto farmacêutico (soro de látex natural Hevea brasiliensis). São Paulo; 2012. 
Received in: 06/10/2015

Accepted for publication: 21/12/2015

Conflict of interest: none.

Source of funding: none.
Mailing address:

João Batista de Sousa

E-mail: sousajb@unb.br 